\title{
APPLYING THE ANTICIPATORY FAILURE \\ sciendo \\ DETERMINATION AT A VERY EARLY STAGE OF A SYSTEM'S DEVELOPMENT: OVERVIEW AND CASE STUDY
}

doi:10.2478/mape-2018-0027

Date of submission of the article to the Editor: 04/2018

Date of acceptance of the article by the Editor: 06/2018

MAPE 2018, volume 1, issue 1, pp. 205-215

\author{
DSc., Dr Leszek Chybowski \\ DSc., Dr Katarzyna Gawdzińska \\ Maritime University of Szczecin, Poland \\ Mr. Valeri Souchkov \\ ICG Training \& Consulting, Netherlands
}

\begin{abstract}
Anticipatory Failure Determination (AFD) is a tool used in the TRIZ (Theory of Inventive Problem Solving) methodology. This article introduces its concept and describes the process of AFD in different versions of the method. The article presents the application of the AFD method at a very early state of a system's development, i.e. its concept formulation stage, which corresponds to a technology readiness level ( $T R L)$ equal to 2 . The system under analysis is a set of devices used to reduce displacement ship hull resistance. The system was modelled using functional analysis. An analysis of system resources was then carried out. Possible direct, indirect, and accident-related failures were identified. A multi-criteria analysis of the causes of system failures was conducted from which the top 10 potential failures were selected. Observations were made on the applicability of AFD in respect to systems not yet implemented.
\end{abstract}

Keywords: complex technical system, anticipatory failure determination - AFD, anticipatory failure analysis - AFA, failure prediction, Theory of Inventing Problem Solving - TRIZ

\section{INTRODUCTION}

TRIZ, is the Russian acronym for the Theory of Inventing Problem Solving. It is the life's work of Genrich Altshuller, his associates and the successors of his ideas for developing ARIZ (Algorithm for Inventive Problem Solving) (Mayer, 2017; Oxford Creativity, 2017). TRIZ is a complex methodology comprising a range of tools for proper definition and modelling of a problem situation (inventive task), structured problem solution finding, and evaluation and selection of the most effective solutions (Howard et al., 2009).

There are a range of methods to simulate the process of failure prediction in complex technical systems including: Failure Modes and Effects Analysis (FMEA), Hazard and Operability Analysis (HAZOP), Preliminary Hazards Analysis (PHA), Risk Assessment, Fault Tree Analysis (FTA) and Event Tree Analysis (ETA). TRIZ also provides tools for solving inventive problems in terms of the identification of causes and consequences of the occurrence of undesirable situations such as failures, errors, environmental impact, and intentional and unintentional effects of human action. Anticipatory Failure Determination (AFD) (Kaplan et al., 1999), also called Anticipatory Failure Analysis (AFA) (Souchkov, 2016), is one such tool. This method is based on a previous tool called subversion analysis, also known as sabotage analysis, which used concepts named the opposite experiment which were method for solving R\&D problems developed by Voluslav Mitrofanov, a founder of the Leningrad University of Technical Creativity (Chybowski et al., 2018). Subversion Analysis method was originated by Mitrofanov's student Boris Zlotin in 1977. Later it were 
developed in 1984 jointly with Alla Zusman (Zlotin and Zusman, 1991) and finally by Svetlana Visnepolchi (2008). Subversion analysis allows for identifying hypotheses regarding the explanation of causes of a given effect and also helps to choose the most likely hypotheses. The tool is very useful in the identification of causes of given phenomena and events (faults, errors, negative impact), especially in situations where causes cannot be easily determined (Chybowski et al. 2018). Subversion Analysis is concerned with prediction and evaluation of consequences of potential undesirable effects, which makes it applicable to already existing, as well as newly developed products and technologies, including single units or units belonging to small product families (nuclear power plants, space ships, lunar vehicles, specialized marine vessels, etc.). The method was transferred to USA and renamed to the AFD. It is based on the inversion of the original question of 'What to do to make a system work correctly?' to the question of 'How to make a given failure occur?'

\section{METHODOLOGY}

AFD is a method aimed at finding possible unexpected and undesirable events that risk disrupting the normal operation of a technical system, with the use of existing resources (Fig. 1). This tool was created in the 1980's (Altshuller et al., 1989; Ungvari, 1999; Zlotin and Zusman, 1991) by Boris Zlotin and Alla Zusman (Kaplan, 1997; Proseanic et al, 2000). This method was computerised by Ideation International Inc. in Detroit, MI, USA (Ungvari, 1999), and is available in the form of two products: Ideation Failure Analysis ${ }^{\mathrm{TM}}$ and Ideation Failure Prediction $^{\mathrm{TM}}$ (Zusman and Smith, 1991). The two main algorithms are AFD-1 and AFD-2, further described in (Kaplan et al., 1999). AFD has also seen other modifications including AFD-3, integrated AFD, and the xTRIZ Anticipatory Failure Analysis.

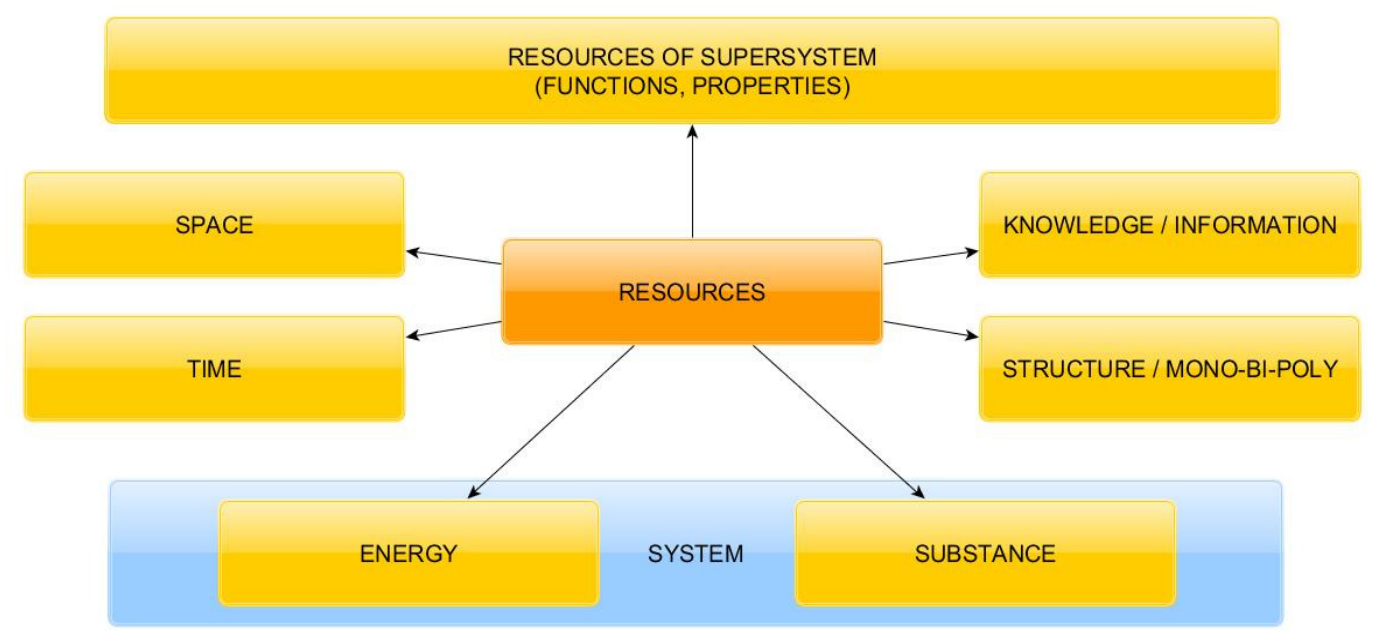

Fig. 1. Categories of resources in terms of type and place of availability Source: (Chybowski et al., 2018).

Potential failure is a result of unforeseen and undesired negative factors resulting from a combination of the function performed within the system, and the resources available in given conditions.

\section{Failure Analysis (AFD-1)}

The AFD-1 algorithm is used to identify the causes of failure that has already occurred. It has been described in detail in (Kaplan et al., 1999). The individual steps in the process are:

1. Formulating the original problem.

2. Identifying a success scenario.

3. Locating failure.

4. Formulating and amplifying the inverted problem. 
5. Searching for solutions.

5.1. Searching for apparent or obvious solutions.

5.2. Identifying resources.

5.3. Utilising resources and searching for needed effects.

5.4. Applying "ARIZ for AFD"

5.4.1. Recapping the problem

5.4.2. Formulating the secondary problem(s).

5.4.3. Formulating the ideal solution of the secondary problem.

5.4.4. Searching for ways to achieve the ideal solution.

6 . Formulating hypotheses and designing tests to verify them.

7. Correcting failure.

\section{Failure Prediction (AFD-2)}

The AFD-2 algorithm is used for the prediction and identification of failure that has not yet occurred. It has been described in detail in (Kaplan et al., 1999). The individual steps in the process are:

1. Formulating the original problem.

2. Identifying the success scenario.

3. Formulating the inverted problem.

4. Searching for obvious possible failures.

5. Identifying available resources.

6. Utilising the knowledge base.

7. Inventing new solutions by applying "ARIZ for failure prediction".

7.1. Formulating a general way to produce the desired effect and the secondary problem.

7.2. Formulating the ideal conditions for realising the harmful effect.

7.3. Searching for ways to achieve the ideal conditions.

7.4. Searching for the way to change the system.

8. Intensifying and masking harmful effects.

9. Analysing relevant harmful effects.

7. Preventing and eliminating harmful effects.

\section{Human Factor Analysis (AFD-3)}

The AFD-3 method was presented in (Sunday, 2014) as a response to potential limitations of AFD-1 and AFD-2 in terms of prediction of failure associated with human errors, organizational errors, bad ergonomic design, and other manufacturing defects. The AFD-3 method is a continuation of AFD-1 and consists of the following steps:

1. Formulating the original problem.

2. Identifying the success scenario.

3. Locating failure.

3.1. Mapping system dependency to design structure matrix (DSM).

3.2. Identifying failure.

4. Formulating the problem at the subsystem's level.

5. Stating the success scenario at the subsystem's level.

6. Locating failure at the component level.

7. Gathering the required information.

7.1. Consulting the design documentation.

7.1. Mapping design matrix (DM) information to DSM.

8. Locating failure at the design parameter (DP) level.

9. Locating the DP failure at the process domain.

10. Formulating, inverting, and amplifying the problem.

11. Searching for a solution.

11.1. Searching for an apparent solution. 
11.1. Identifying resources in the manufacturing process.

11.1. Utilising the identified resources to produce the DP problem.

11.1. Applying ARIZ.

12. Formulating and verifying hypotheses.

13. Implementing a solution to the problem.

\section{Integrated AFD Method}

Andreas Jensen and Terje Aven at the University of Stavanger proposed a modification of the AFD-1 method, that consisted of a generalization of the stages of solution finding (AFD1, point 5), i.e. the use of an alternative creative method (Jensen and Aven, 2015a; Jensen and Aven 2015b). Hence, in addition to/instead of the application of ARIZ, they offered the use of brainstorming (the Osborne-Parnes model) or De Bono lateral thinking, as well as other inventive methods (Howard et al., 2009).

\section{xTRIZ Anticipatory Failure Analysis}

In (Souchkov, 2016) the approach to AFD was modified by the introduction of combinations between functions and resources which, under certain conditions, lead to the occurrence of failure. Failure, seen within the framework of a system's function model, can be divided into:

1. Direct Potential Failure - directly related to the failure factor (failure mode) associated with a given function (relation) that exists between two system components.

2. Indirect Potential Failure - related to the failure mode associated with the impact between two components which are not directly linked functionally, but do interact through an intermediary.

3. Accident-Related Failure - related to an unexpected and unplanned change in the operating conditions of the system, or a change in its environment (supersystem).

Here, the basic element is the functional modelling of the system. This approach is also significant thanks to the introduction of the evaluation stage of individual identified causes of failure, in terms of severity. Individual steps of the algorithm are:

1. Selecting a system to analyse.

2. Defining the stage of a system's operation / stage of the life cycle.

3. Building a function model of the system and the supersystem.

3.1. Defining subsystems and supersystem of the analysed system.

3.2. Defining functions between components of subsystems and the supersystem.

4. Creating the list of functions.

5. Identifying available resources.

6. Checking how combinations of functions and resources can create failures (it is important since not each combination can create failure).

7. Estimating indirect and environmental impacts.

8. Searching for generic causes of failures not indicated at previous stages.

9. Ranking potential failures and accidents.

9.1. Bringing all the failures on a single list.

9.2. Defining a list of potential top 10 most critical failures.

9.3. Ranking the probability of each potential failure and degree of its impact.

\section{APPLICATION OF AFD IN A SYSTEM IN ITS CONCEPTUAL DEVELOPMENT STAGE System Description}

AFD was used as the example in the evaluation of the failure tolerance of systems of low technology readiness level (NASA, 2017). In this case study, the method of proceeding described in section 3.3 was applied, due to the fact that it embraces elements of all the previously presented approaches. The object of the analysis was a newly developed system for the minimization of hull resistance and removal of lichen covering displacement vessels that is the subject of a patent application (Chybowski, 2017a). The general view of the 
system is shown in Figure 2. The essence of the solution applied in the invention is based on the fact that the hull plating, 1, has integrated heaters below the waterline, 3 , that generate gas particles, 6 . The heaters are connected to the control system, 4 (by means of feedback in the form of the heater temperature signal), and the actuating system, 5 (providing power for the heaters), while the hull was covered with a cavitation and heat resistant coating.

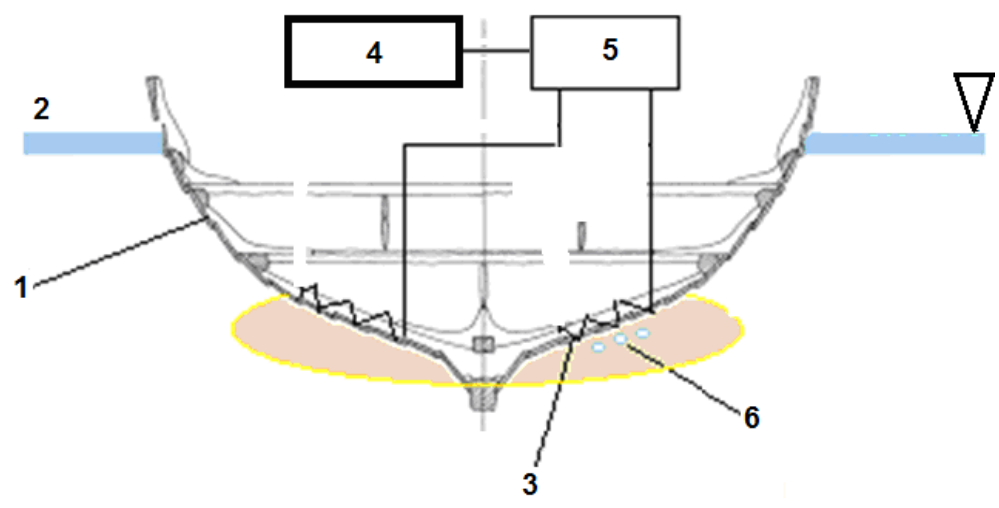

Fig. 2. General view of the analysed system (description in text)

The number of gas particles generated by the steam or electric heaters depended on the heating temperature specified by the control system, on the basis of information about the heater temperature and/or the outboard water temperature and/or vessel draft and/or vessel speed and/or depth of water area and/or swimming area, describing water salinity and the possibility for growth of living organisms as defined by the operator. The solution employs thermal energy provided by the heaters to generate steam using sea water, and extract air contained in the sea water in order to remove the lichen covering the hull, and to form a layer of gas (bubbles of steam and air) encircling the hull. By reducing hull resistance it is possible to obtain higher speeds in displacement ships, while reducing the amount of fuel used which, consequently, leads to a reduction in the amount of polluting substances produced as a result of fuel combustion and emitted by ships: $\mathrm{CO}_{2}, \mathrm{NOx}$ and SOx. (Midor et al., 2018).

\section{Function Modelling and Resources analysis}

Analysis can be conducted for different stages of the life cycle, including in particular: production of raw materials, manufacturing of the system, transportation of the system, storage of the system, starting the system, operation of the system, system's maintenance by ship's crew, system's maintenance by divers, system's maintenance by shipyard in the dry dock, utilisation of the system, and recycling materials. This analysis was conducted for the system operation phase.

For the analysed system a function model was built, which is presented in Figure 3.

For the purpose of system modelling the following hierarchy of components was adopted:

1. The supersystem level of the analysed system:

- "supersystem product" - ship's hull (including cavitation and temperature protective layer),

- other supersystem components: operator, water, steam bubbles.

2. The analysed system: steam bubbles generator.

3. The subsystem level: control unit, supply unit, heaters. 


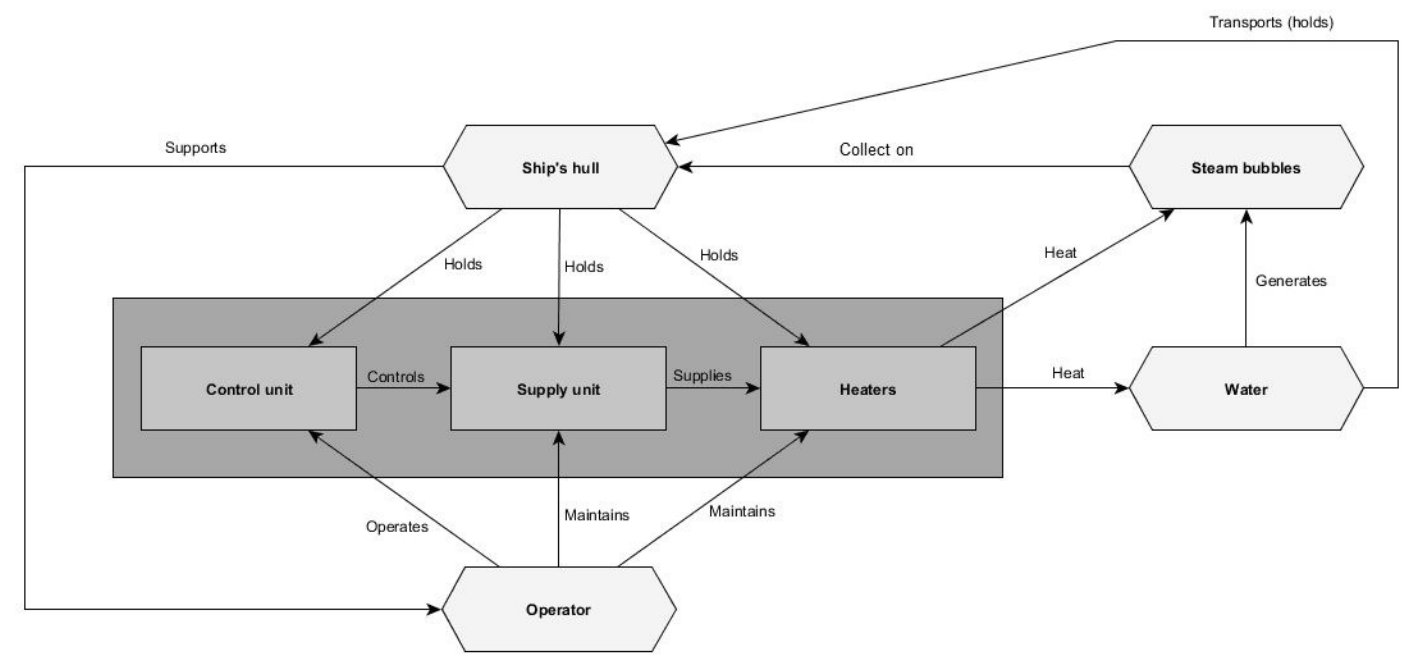

Fig. 3. Function model of the analysed system

For the analysed system, an analysis of resources, set out in Table 1, was conducted and the supersystem components were selected at the modelling stage.

Table 1

Function specific resources

\begin{tabular}{|c|c|c|}
\hline Number & Category & Specific resources \\
\hline 1 & Time & $\begin{array}{l}\text { Operation time of heaters (life time) } \\
\text { Intervals between bubbling } \\
\text { Time from last maintenance } \\
\text { Time to next maintenance } \\
\text { Short operation time (voyage/trip time) }\end{array}$ \\
\hline 2 & Space & $\begin{array}{l}\text { Effective heat exchanging area of heaters } \\
\text { Volume of steam bubbles zone } \\
\text { Volume of machinery compartments } \\
\text { Total hull volume }\end{array}$ \\
\hline 3 & Substance / Materials & $\begin{array}{l}\text { Metal } \\
\text { Water (liquid) } \\
\text { Water (steam bubbles) } \\
\text { Semiconductors } \\
\text { Plastics } \\
\text { Air } \\
\text { Hull coating }\end{array}$ \\
\hline 4 & Energy & $\begin{array}{l}\text { Electrical } \\
\text { Thermal (heat) } \\
\text { Mechanical (hull drag) } \\
\text { Mechanical (propeller thrust) } \\
\text { Mechanical (thrust deduction) } \\
\text { Mechanical (water inertia) } \\
\text { Mechanical (ship inertia) } \\
\text { Mechanical (buoyancy) } \\
\text { Mechanical (cavitation) } \\
\text { Mechanical / acoustic (noise and vibrations) } \\
\text { Gravity }\end{array}$ \\
\hline 5 & Information & $\begin{array}{l}\text { Heaters operational data (temperature, hull fouling etc.) } \\
\text { Overboard water characteristics (density, temperature, air content etc.) } \\
\text { Navigational information (water depth, drought, sheep speed etc.) }\end{array}$ \\
\hline 6 & Additional functional & Human operations (maintenance) \\
\hline
\end{tabular}




\section{Failures Identification}

A list of potential direct failures, summarized in Table 2, was created for identified resources and system functions. In the next stage, potential indirect failures and accident-related failures, presented respectively in Tables 3 and 4, were sought.

\section{Table 2}

Identifying direct potential failures (function + resources)

\begin{tabular}{|c|l|l|}
\hline Number & \multicolumn{1}{|c|}{ Function } & \multicolumn{1}{|c|}{ Potential failures } \\
\hline 1 & Hull holds control unit & $\begin{array}{l}\text { Heaters burned (overheated) } \\
\text { Heaters heated only partly } \\
\text { Heaters are out of control }\end{array}$ \\
\hline 2 & Hull holds supply unit & Heater is lost \\
\hline 3 & Hull holds heaters & $\begin{array}{l}\text { Insufficient steam generation } \\
\text { Over-generation of steam bubbles }\end{array}$ \\
\hline 5 & Control unit controls supply unit & $\begin{array}{l}\text { Heaters are off } \\
\text { Heaters burned (overheated) }\end{array}$ \\
\hline 6 & Operator operates control unit & $\begin{array}{l}\text { Operator shocked by electricity } \\
\text { Heaters are out of control }\end{array}$ \\
\hline 7 & Operator maintains supply unit & $\begin{array}{l}\text { Operator shocked by electricity } \\
\text { Heaters are out of control }\end{array}$ \\
\hline 8 & Operator maintains heaters & $\begin{array}{l}\text { Operator shocked by electricity } \\
\text { Operator burned by heater } \\
\text { Heaters are out of control }\end{array}$ \\
\hline 9 & Heaters heat water & Heater is cracked (by thermal overloading) \\
\hline 10 & Heaters heat steam bubbles & Bubbles damage hull due to cavitation \\
\hline 11 & Water generates steam bubbles & $\begin{array}{l}\text { Bubbles generate wave effects which increases friction } \\
\text { Bubbles generate wave effects which increases noise }\end{array}$ \\
\hline 12 & Steam bubbles collect on the hull & Water floods into internal compartments of the hull \\
\hline 13 & Water transports (holds) the hull & Loss of system supervision by the operator \\
\hline 14 & Hull supports operator &
\end{tabular}

Table 3

Identifying indirect potential failures

\begin{tabular}{|c|l|l|}
\hline Number & \multicolumn{1}{|c|}{ Failure function } & \multicolumn{1}{c|}{ Potential failures } \\
\hline 1 & $\begin{array}{l}\text { Ship's power plant failures (black- } \\
\text { out) }\end{array}$ & System is temporarily out of service \\
\hline 2 & $\begin{array}{l}\text { Animals or humans enters the steam } \\
\text { bubbles zone in the water }\end{array}$ & Death of human or animal in the water \\
\hline 3 & $\begin{array}{l}\text { Operator made mistakes while } \\
\text { operating the system due to external } \\
\text { circumstances }\end{array}$ & $\begin{array}{l}\text { Operator shocked by electricity } \\
\text { Operator burned by heater }\end{array}$ \\
\hline
\end{tabular}

Table 4

Identifying accident-related failures

\begin{tabular}{|c|l|l|}
\hline Number & \multicolumn{1}{|c|}{ Non-planed change } & \multicolumn{1}{c|}{ Potential failures / accidents } \\
\hline 1 & Ship grounding & $\begin{array}{l}\text { Serious mechanical damage of heaters (system down) } \\
\text { Water floods into internal compartments of the hull }\end{array}$ \\
\hline
\end{tabular}

The results obtained are summarised in the final list of potential failures:

1. Heaters burned (overheated)

2. Heater is cracked (by thermal overloading)

3. Heaters heated only partly

4. Heaters are out of control

5. Heater is lost

6. Insufficient steam generation

7. Over-generation of steam bubbles

8. Operator shocked by electricity 
9. Operator burned by heater

10. Bubbles damage hull due to cavitation

11. Bubbles generate wave effects which increases friction

12. Bubbles generate wave effects which increases noise

13. Water floods into internal compartments of the hull

14. Loss of system supervision by the operator

15. Death of human or animal in the water

16. Serious mechanical damage of heaters (system down)

17. System is temporarily out of service

18. Heaters are off

\section{DISCUSION}

Identified potential failure was evaluated by means of a multi-criteria analysis. Each type of failure was assessed on a scale from 0 to 1 , in terms of 8 criteria which were the following:

$\mathrm{C} 1$ - Degree of probability

C2 - Degree of disrupting a process (process severity)

$\mathrm{C} 3$ - Degree of damage to humans

C4 - Degree of damage to a technical system (product severity)

C5 - Degree of damage to supersystem (except humans)

C6 - Degree of damage to environment

C7 - Relative total cost failure

C8 - Degree of reoccurrence under the same conditions

A comparison of the assessment results is presented in Table 5.

Table 5 Multi-criteria evaluation of identified failures

\begin{tabular}{|l|c|c|c|c|c|c|c|c|c|}
\hline \multicolumn{1}{|c|}{ Failure / accident } & C1 & C2 & C3 & C4 & C5 & C6 & C7 & C8 & Sum \\
\hline Heaters burned (overheated) & 0.5 & 0.8 & 0.0 & 1.0 & 0.0 & 0.0 & 0.6 & 0.8 & $\mathbf{3 . 7}$ \\
\hline $\begin{array}{l}\text { Heater is cracked (by thermal } \\
\text { overloading) }\end{array}$ & 0.2 & 1.0 & 0.0 & 1.0 & 0.0 & 0.0 & 0.6 & 0.6 & $\mathbf{3 . 4}$ \\
\hline Heaters heated only partly & 0.8 & 0.5 & 0.0 & 0.5 & 0.0 & 0.0 & 0.4 & 0.5 & $\mathbf{2 . 7}$ \\
\hline Heaters are out of control & 0.5 & 0.5 & 0.0 & 1.0 & 0.0 & 0.0 & 0.2 & 0.5 & $\mathbf{2 . 7}$ \\
\hline Heater is lost & 0.1 & 1.0 & 0.0 & 1.0 & 1.0 & 0.0 & 1.0 & 0.2 & $\mathbf{4 . 3}$ \\
\hline Insufficient steam generation & 0.5 & 0.5 & 0.0 & 0.0 & 1.0 & 0.0 & 0.2 & 0.5 & $\mathbf{2 . 7}$ \\
\hline Over-generation of steam bubbles & 0.1 & 0.0 & 0.0 & 0.0 & 1.0 & 0.0 & 0.0 & 0.2 & $\mathbf{1 . 3}$ \\
\hline Operator shocked by electricity & 0.2 & 0.0 & 1.0 & 0.0 & 1.0 & 0.0 & 1.0 & 0.9 & $\mathbf{4 . 1}$ \\
\hline Operator burned by heater & 0.1 & 0.0 & 1.0 & 0.0 & 1.0 & 0.0 & 1.0 & 0.8 & $\mathbf{3 . 9}$ \\
\hline Bubbles damage hull due to cavitation & 0.8 & 0.0 & 0.0 & 0.0 & 1.0 & 0.0 & 0.8 & 1.0 & $\mathbf{3 . 6}$ \\
\hline $\begin{array}{l}\text { Bubbles generate wave effects which } \\
\text { increases friction }\end{array}$ & 0.5 & 0.0 & 0.0 & 0.0 & 1.0 & 0.0 & 0.1 & 0.5 & $\mathbf{2 . 1}$ \\
\hline $\begin{array}{l}\text { Bubbles generate wave effects which } \\
\text { increases noise }\end{array}$ & 1.0 & 0.0 & 0.2 & 0.0 & 1.0 & 1.0 & 0.1 & 0.8 & $\mathbf{4 . 1}$ \\
\hline $\begin{array}{l}\text { Water floods into internal compartments } \\
\text { of the hull }\end{array}$ & 0.1 & 1.0 & 1.0 & 1.0 & 1.0 & 1.0 & 1.0 & 0.5 & $\mathbf{6 . 6}$ \\
\hline $\begin{array}{l}\text { Loss of system supervision by the } \\
\text { operator }\end{array}$ & 0.9 & 0.5 & 1.0 & 0.5 & 1.0 & 0.5 & 0.6 & 0.9 & $\mathbf{5 . 9}$ \\
\hline Death of human or animal in the water & 0.1 & 0.0 & 0.0 & 0.0 & 1.0 & 1.0 & 1.0 & 0.9 & $\mathbf{4 . 0}$ \\
\hline $\begin{array}{l}\text { Serious mechanical damage of heaters } \\
\text { (system down) }\end{array}$ & 0.3 & 1.0 & 0.0 & 1.0 & 1.0 & 0.0 & 0.6 & 0.9 & $\mathbf{4 . 8}$ \\
\hline System is temporarily out of service & 0.8 & 1.0 & 0.0 & 0.0 & 0.1 & 0.0 & 0.1 & 1.0 & $\mathbf{3 . 0}$ \\
\hline Heaters are off & 0.5 & 1.0 & 0.0 & 0.0 & 0.1 & 0.0 & 0.1 & 1.0 & $\mathbf{2 . 7}$ \\
\hline
\end{tabular}

The overall score-based assessment of fulfilment of the criteria C1-C8 allowed for the creation of a top 10 ranking of potential failures which are:

1. Water floods into internal compartments of the hull.

2. The system is not supervised by the operator.

3. There is serious mechanical damage of heaters (system down). 
4. The heater is lost.

5. The operator is shocked by electricity.

6. Bubbles generate wave effects which increases noise.

7. Humans or animals die in the water.

8. The operator is burned by heater.

9. Heaters burned (overheated)

10.Bubbles damage hull due to cavitation.

\section{CONCLUSION}

The source literature features case studies describing the use of AFD for such systems as, among others, an automotive engine (Proseanic et al., 2000; Smith and Phadke, 2005), a cable (Zihui and Rong, 2010), a mountain expedition (Jensen and Aven, 2015a; Jensen and Aven, 2015b), a production platform (Jensen and Aven, 2015c), and an optical system (Sunday, 2014). In the conducted analysis, an evaluation was made of a system not yet in operation (a system in its conceptual phase). This approach can be applied to other systems with a low technology readiness level (Chybowski and Kuźniewski, 2016).

For the analysis of system failure tolerance, the XTRIZ algorithm described in section 3.3 was used, as it included all the previously mentioned elements. These elements include direct and indirect failure search (which was the basis for AFD-1 and AFD-2), as well as accident-related failures (which constitutes the main objective of the AFD-3 method). The XTRIZ approach combines system modelling, resource analysis, potential failure search and multi-criteria evaluation of the obtained results.

It should be noted that the presented approach is not limited to the use of one or other inventive methods (TRIZ methods of solving inventive problems and non-TRIZ methods), which means that it shares common elements with the integrated AFD. Various methods can be applied for this purpose (Derlukiewicz et al., 2016; Zusman and Smith, 2016). The analysis presented is part of a larger project, and the system under evaluation is the result of the application of ARIZ for finding methods of reducing fuel consumption in ships.

Searching for potential failure can be supported by means of specialised software such as the aforementioned Ideation Failure Analysis ${ }^{\mathrm{TM}}$ and Ideation Failure Prediction ${ }^{\mathrm{TM}}$ (Kaplan et al., 1999), as well as on the basis of different physical chemical, biological, geometrical, and even psychological effects (AULIVE, 2017; Bejger and Gawdzińska, 2011; Boratyńska-Sala, 2016; Oxford Creativity 2017; Pajor et al., 1999; Zaplata and Pajor, 2016; Zolkiewski 2013).

The ranking of the identified failures can also be made using various methods, including in addition to the aforementioned assessment matrix, a weighted average as well as methods based on direct comparisons of failure-related values of individual assessments, and the importance of individual evaluation criteria. Particularly useful here is the Analytical Hierarchy Process (AHP) method, which was successfully applied as a tool supporting TRIZ (Chybowski et al. 2017).

The direction of further development for AFD seems to be its use in the assessment of the quality of products and the structure of advanced materials, as a supplement to methods currently used (Biały 2014; Cempel, 2013; Chybowski, 2017b; Gawdzińska et al., 2016).

\section{ACKNOWLEDGMENTS}

The research presented in this article was carried out under the Grant of the Ministry of Science and Higher Education of Poland $\mathrm{nr}$ 1/S/IESO/17: "Increasing operational effectiveness of complex technical systems by systematic development and implementation of innovations using novel materials and modifying the object's structure" performed at the Maritime University of Szczecin, Poland. 


\section{REFERENCES}

Altshuller, G., Zlotin, B., Zusman, A., Filatov, V. (1989). Poisk nowych idiej: ot ozarienijak tiechnołogii (Searching for New Ideas). Kiszeniew: Kartia Mołdowieniaske.

AULIVE (2017). Product Inspiration. [online] AULIVE. Available at: http://www.productioninspiration.com/ [Accessed: 15 Jul. 2017].

Bejger, A., Gawdzińska, K. (2011). Identification of Structural Defects of Metal Composite Castings with the Use of Elastic Waves. Archives of Metallurgy and Materials, Vol. 56, Issue 1, pp. 129-133, doi: 10.2478/v10172-011-0014-z.

Biały, W. (2014). Innovative solutions in the overhaul of the main fan of the ventilation system in a mine. Scientific Journals of the Maritime University of Szczecin, Zeszyty Naukowe Akademii Morskiej w Szczecinie, 39(111), pp. 25-30.

Boratyńska-Sala A. (2016). Banki „efektów” w teorii i praktyce TRIZ (Effectiveness of database in the theory and practice of TRIZ). Zarządzanie Przedsiębiorstwem, Vol. 19, nr 4, pp. 2-9.

Cempel, C. (2013). Inżynieria kreatywności w projektowaniu innowacji. Radom - Poznań: ITE - PIB, pp. 131-157.

Chybowski, L. (2017a). Sposób i układ minimalizacji oporu kadłuba i usuwania porostów wypornościowego statku wodnego (Method and system for minimization of hull resistance and removal of fouling covering displacement vessels). Patent application: P.423394, 09 Nov. 2017, Polish Patent Office.

Chybowski, L. (2017b). The usage of the Miniature Dwarfs method in the improvement of passenger ship construction. Scientific Journals of the Maritime University of Szczecin, Zeszyty Naukowe Akademii Morskiej w Szczecinie, nr 51 (123), pp. 28-34, doi: 10.17402/227.

Chybowski, L., Bejger, A., Gawdzińska, K. (2018). Application of Subversion Analysis in the Search for the Causes of Cracking in a Marine Engine Injector Nozzle. World Academy of Science, Engineering and Technology International Journal of Industrial and Manufacturing Engineering. Vol.12, No. 4, 2018, pp. 302-308.

Chybowski, L., Gawdzińska, K., Przetakiewicz, W. (2017). AHP based multi-criteria function analysis as a TRIZ tool for complex technical systems (Ed. Valeri Souchkov) Proceedings of the 13th MATRIZ TRIZfest 2017 International Conference. September 14-16, 2017. Kraków, Poland. International TRIZ Association - MATRIZ, Knoxville 2017, pp. 31-45.

Chybowski, L., Kuźniewski, B. (2016). Utilising water wave energy - technology profile. Scientific Journals of the Maritime University of Szczecin, Zeszyty Naukowe Akademii Morskiej w Szczecinie, 47(118), pp. 183-186, doi: 10.17402/167.

Derlukiewicz, D., Ptak, M., Koziołek, S. (2016). Proactive Failure Prevention by Human-Machine Interface in Remote-Controlled Demolition Robots. Advances in Intelligent Systems and Computing, Volume 445, pp. 711-720.

Gawdzińska, K., Chybowski, L., Przetakiewicz, W. (2016). Proper matrix-reinforcement bonding in cast metal matrix composites as a factor of their good quality. Archives of Civil and Mechanical Engineering, 16(3), pp. 553-563, doi: 10.1016/j.acme.2015.11.004.

Howard ,T., J., Culley, S., J., Dekoninck, E., A. (2009). Stimulating Creativity: A More Practical Alternative to TRIZ. Proceedings of ICED 09 - the 17th International Conference on Engineering Design, Stanford University, Stanford, CA, Vol. 5, pp. 205-216, [online] Available at: https://www.designsociety.org/publication/28693/stimulating_creativity_a_more_practical_altern ative_to_triz [Accessed: 02 Nov. 2017].

Jensen, A., Aven, T. (2015a). Case studies on Hazard/threat identification - using different creative methods to support the Anticipatory Failure Determination approach. [online] Available at: http://www6.uis.no/ansatt/jensen/ [Accessed: 02 Feb. 2018].

Jensen, A., Aven, T. (2015b). Hazard/threat identification-using different creative methods to support the Anticipatory Failure Determination approach. Safety and Reliability of Complex Engineered Systems (Eds. L. Podofillini et al.). Proceedings of the 25th European Safety and Reliability Conference ESREL 2015, pp. 801-806.

Jensen, A., Aven, T. (2015c). Using the AFD threat identification based approach to generate potential risk reduction measures - an example. [online] Available at: http://www6.uis.no/ansatt/jensen/ [Accessed: 02 Nov. 2017].

Kaplan, S. (1997). Finding Failures before They Find Us: An Introduction to The Theory of Scenario Structuring and the Method of Anticipatory Failure Determination. Proceedings of the 9th Symposium on Quality Function Deployment, June, 1997.

Kaplan, S., Visnepolschi, S., Zlotin, B., Zusman, A. (1999). New Tools for Failure and Risk analysis. Anticipatory Failure Determination ${ }^{\circledR}$ (AFD) and the Theory of Scenario Structuring. Detroit: Ideation International Inc.

Mayer, O. (2017). Flexible lighting distribution on "party ships". Scientific Journals of the Maritime University of Szczecin, Zeszyty Naukowe Akademii Morskiej w Szczecinie, 49(121), pp. 9-16, doi: 10.17402/195.

Midor, K., Klimecka-Tatar, D., Chybowski, L. (2017). Innowacje w przemyśle - wybrane aspekty. (Innovations in the industry - selected issues). Gliwice: PA NOVA S.A., 
NASA (2017). Definition Of Technology Readiness Levels. [online] NASA website. Available at: https://esto.nasa.gov/files/TRL_definitions.pdf [Accessed: 27 Dec. 2017].

Oxford Creativity (2017) TRIZ Effects Database. [online] Oxford Creativity. Available at: http://wbam2244.dns-systems.net//EDB_Welcome.php [Accessed: 15 Jul. 2017].

Pajor, M., Marchelek, K., Powalka, B. (1999). Experimental verification of method of machine tool cutting process system model reduction in face milling. Computational Methods and Experimental Measurements IX, pp. 503-512.

Proseanic, V., Tananko, D., Visnepolschi, S. (2000). The experience of the Anticipatory Failure Determination (AFD) method applied to Hitching/Ringing Problems. TRIZCON2000, The Second Annual Altshuller Institute TRIZ Conference Proceedings, Nashua, 2000, pp. 119-126.

Smith, L., R., Phadke, M., S. (2005). Some Thoughts about Problem Solving in a DMAIC Framework. Int. J. Six Sigma and Competitive Advantage, Vol. 1, No. 2, pp. 151-166.

Souchkov, V., V. (2016). Anticipatory Failures analysis. Training Course. Module of MATRIZ Level 3 Certification Training. Enschede: ICG Training \& Consulting.

Sunday, E. (2014). Extension and Modification of Anticipatory Failure Determination Approach Based on I-TRIZ. M.S. Thesis supervised by T. Aven. University of Stavanger. [online] Available at: https://brage.bibsys.no/xmlui/handle/11250/223619 [Accessed: 02 Nov. 2017].

Ungvari, S. (1999). The Anticipatory Failure Determination Fact Sheet. [online] TRIZ-Journal. Available at: http://www.metodolog.ru/triz-journal/archives/1999/10/a/index.htm [Accessed: 31 Sep. 2017].

Visnepolschi, S. (2008). How to Deal with Failures (The Smart Way). Southfield: Ideation International Inc..

Zaplata, I, Pajor, M. (2016). The Influence of Presumed Border Conditions on FEM Thermal Analysis Results Based on the Example of an LNG Tank Support Saddle. Advances in Mechanics: Theoretical, Computational and Interdisciplinary Issues, pp. 601-604.

Zihui, W., Rong, C. (2010). Research of the Failure Cause Analysis and Solving Model Based on TRIZ\& AFD. 2010 International Conference on Computer Design and Applications (ICCDA 2010), Vol. 5, pp. 617-620.

Zlotin, B., Zusman, A. (1991). Rieszenije issledowatielskich zadacz (Solving All Scientific Problems). Kiszeniew: Kartia Mołdowieniaske.

Zolkiewski, S. (2013). Vibrations of beams with a variable cross-section fixed on rotational rigid disks. Latin American Journal of Solids and Structures, Vol. 10, Issue 1, pp. 39-57.

Zusman, A., Smith, L., R. (2016). I-TRIZ (Ideation TRIZ). In: The Innovation Tools Handbook, Volume 3: Creative Tools, Methods, and Techniques that Every Innovator Must Know (Ed. H. J. Harrington, F. Voehl). Boca Raton - London - New York: CRC Press, pp. 151-194. 